\title{
Gangliosides Inhibit Glucosylceramide Synthase: A Possible Role in Ganglioside Therapy
}

\author{
Girja S. Shukla, Arti Shukla, and Norman S. Radin \\ Mental Health Research Institute, The University of Michigan, Ann Arbor, Michigan, U.S.A.
}

\begin{abstract}
Gangliosides stimulate the hydrolysis of glucosylceramide (GlcCer), their precursor, and therefore may lower the level of cellular GlcCer and exert a feedback control effect to slow the formation of gangliosides. Tests were made to see if a similar effect on GlcCer levels can be exerted by the action of gangliosides on GlcCer synthesis. Using a new assay procedure, we showed that gangliosides do inhibit the synthase in brain membranes quite effectively, the most active being those lipids with more sugar and sialic acid moieties. Mice injected with a mixture of brain gangliosides for 5 days were found to have a lower level of ceramide:UDP-Glc glucosyltransferase activity in brain, liver, and kidney. The inhibition seems to be exerted by competition for the active site and binding to effector site(s) on the enzyme. It is possible that
\end{abstract}

the reported therapeutic actions of gangliosides on the nervous system are, in part, the result of lowered levels of GlcCer. Malignant tumors shed gangliosides into the extracellular fluid, which are believed to block the generation of antibodies by the host's immunodefense system; this effect also may be due, in part, to reduction in the GlcCer level of immunogenic cells. A new finding is that a ceramide containing phytosphingosine is a markedly better substrate for GlcCer synthase than one containing the more common base. Key Words: Ganglioside-Glucosylceramide synthase-Modulation of glycolipid synthesis-Octanoyl phytosphingosine. Shukla G. S. et al. Gangliosides inhibit glucosylceramide synthase: A possible role in ganglioside therapy. $J$. Neurochem. 56, 2125-2132 (1991).
Glucosylceramide (GlcCer) occupies an important branch control position in sphingolipid metabolism. It is the precursor of all the glucose-based sphingolipids (GSLs) and its precursor, ceramide, has only two other known anabolic roles, the syntheses of galactosylceramide and sphingomyelin. The proposal has been offered that the level of GlcCer in cells controls their rate of cell proliferation. One such relationship is seen in Gaucher patients, who accumulate GlcCer because of defective GlcCer hydrolysis; they exhibit greatly enlarged spleen, liver, and bone marrow. Injection of GlcCer emulsion into mice causes rapid growth of the liver (Datta and Radin, 1988). At low levels in cell media, sphingosine-which is rapidly converted to ceramide (Braun et al., 1970) and, presumably, to GlcCer-produces markedly faster cell proliferation (Zhang et al., 1990). When mice were given eight daily injections of conduritol B epoxide, which inactivates GlcCer glucosidase and causes accumulation of GlcCer, brain and liver became significantly enlarged (Hara and Radin, 1979).
Conversely, reduction in GlcCer level by an inhibitor of GlcCer synthase (ceramide:UDP-Glc glucosyltransferase, EC 2.4.1.80) results in the opposite effect, retardation of cell growth (Inokuchi et al., 1990; J. A. Shayman et al., submitted). It also blocks the proliferative effect of mitogens (Felding-Habermann et al., 1990), the adhesion and migration of tumor cells (Inokuchi et al., 1990), and, in vivo, slows the growth of tumor cells (Inokuchi et al., 1987).

Although the mechanism by which GlcCer exerts this growth effect is still unclear, it is well worth examining the glucosyltransferase's sensitivity to biological factors. Gangliosides are of particular interest because they are products of GlcCer anabolism and might therefore exert some sort of feedback control over the anabolic process. Many therapeutic effects on the nervous system have been claimed to arise from ganglioside injection and gangliosides have often been observed to slow cell growth in vitro. It seemed likely from these observations that gangliosides act as negative modulators on GlcCer synthesis.
Received August 21, 1990; revised manuscript received December 3, 1990; accepted December 10, 1990.

Address correspondence and reprint requests to Dr. N. Radin at 1103 E. Huron, Ann Arbor, MI 48104-1687, U.S.A.
Abbreviations used: DTE, dithioerythritol; GlcCer, glucosylceramide (glucocerebroside); GSL, glucosphingolipid; PDMP, D-threo1-phenyl-2-decanoylamino-3-morpholino-1-propanol. 


\section{MATERIALS AND METHODS}

Gangliosides, long-chain ceramides produced enzymatically from bovine brain sphingomyelin, and most other reagents were from Sigma Chemical. A mixture of gangliosides was prepared from brain by extraction with chloroform/ methanol, partitioning against water, and ion exchange. Short-chain ceramides ( $N$-octanoyl sphingosine and $N$-octanoyl phytosphingosine) were prepared from octanoyl chloride and the corresponding sphingol (Vunnam and Radin, 1979). UDP-D-[6- $\left.{ }^{3} \mathrm{H}\right]$ glucose was from Amersham.

GlcCer synthase was assayed in duplicate or triplicate tubes by modifications of an improved method (Vunnam and Radin, 1979; Shukla and Radin, 1990), using $150 \mu M$ UDPGlc (80,000 cpm); $2 \mathrm{mM}$ ATP; $1 \mathrm{mM}$ dithioerythritol (DTE); $2 \mathrm{~m} M \mathrm{Na}_{2}$ EDTA; $10 \mathrm{~m} M \mathrm{MnCl}_{2} ; 0.1 M$ Tris-Cl- ${ }^{-}$pH 7.4 (at $37^{\circ} \mathrm{C}$ ); and liposomal substrate, in a total volume of 0.2 $\mathrm{ml}$. The lipoidal dispersion consisted of $85 \mu \mathrm{g}$ of octanoyl sphingosine, $565 \mu \mathrm{g}$ of dioleoyl phosphatidylcholine, and 100 $\mu \mathrm{g}$ of brain sulfatide. The radioactive cerebroside that was formed was separated from the precursor by a new partitioning solvent and counted by liquid scintillation. This method yielded a standard deviation of $<3 \%$. Compounds tested for their action on the enzyme were evaporated to dryness from solution in the incubation tube, after which the enzyme-cocktail mixture was pipetted in and incubated for $60 \mathrm{~min}$ in an ultrasonic bath maintained at $37^{\circ} \mathrm{C}$. As enzyme source, in most cases, we used microsomes from brains of 4-month-old mice of the ICR strain, from Harlan Sprague Dawley. The microsomes were prepared by centrifuging a $10 \%$ homogenate in $0.32 \mathrm{M}$ sucrose at $755 \mathrm{~g}$ for $10 \mathrm{~min}$, then at $12,000 \mathrm{~g}$ for $20 \mathrm{~min}$ and at $135,000 \mathrm{~g}$ for $1 \mathrm{~h}$. The pellets were resuspended in the original homogenate volume of sucrose and stored at $-70^{\circ} \mathrm{C}$ in portions. Portions containing 77,99 , and $44 \mu \mathrm{g}$ of protein from each fraction, respectively, were used for the subcellular comparison.

Protein was determined by the bicinchoninic acid method (Smith et al., 1985) with bovine serum albumin as standard.

The data were analyzed by one-way analysis of variance and differences between control and experimental values were considered significant if they reached the $\geq 95 \%$ confidence interval in the Scheffé $F$ test.

\section{RESULTS}

A study with various gangliosides showed that they inhibited the enzyme and that the extent of the effect was smallest with the smallest ganglioside (Fig. 1). Asialo-GM1 was almost inert. At $20 \mu M$, all three of the larger gangliosides had very similar inhibitory effects $(\sim 13 \%)$ but a striking divergence, then a new convergence appeared at higher concentrations (almost complete inhibition at $100 \mu M$ ganglioside). The differences between the individual curves could be ascribed to different affinities for different sites on the enzyme or other microsomal components. The most effective was GDla, which was used for most of the other studies. The inhibitory effect was seen in kidney and liver microsomes as well as in brain.

Tests with 25-100 $\mu M$ concentrations of related compounds, sialic acid, GlcCer, lactosylceramide, sphingomyelin, sphingosine, and phytosphingosine showed them to be inert. Two poly-acids, yeast ribo-

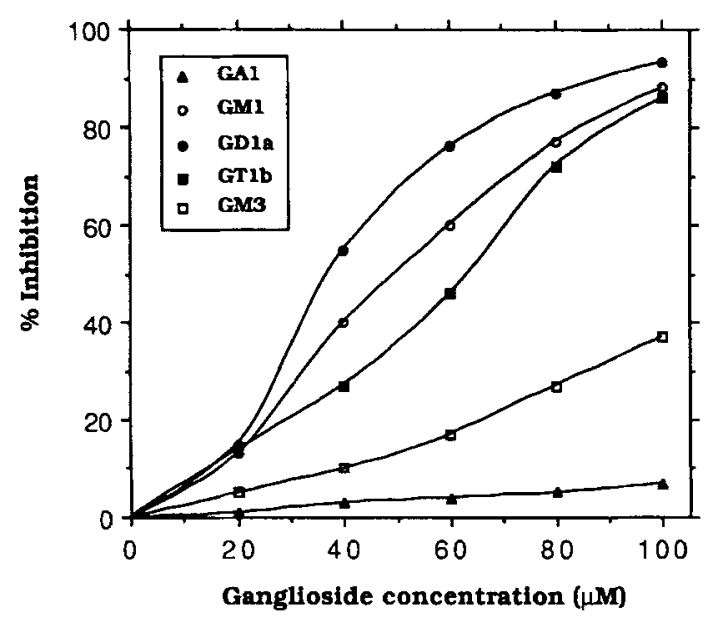

FIG. 1. Effects of different gangliosides and their concentrations on the synthesis of GlcCer. Each tube contained $20 \mu \mathrm{g}$ of protein in the microsomes (derived from $1.6 \mathrm{mg}$ of brain) and the uninhibited basal activity was $388 \mathrm{pmol} / \mathrm{h}$. The data points shown are derived from two experiments; each point is the mean value obtained from four incubation tubes.

nucleic acid and chondroitin sulfate, which resemble gangliosides in their ionic charge, also proved to be inert at $25-100 \mu \mathrm{g} / \mathrm{ml}$.

Some ceramide glucosyltransferase is present in larger particulate fractions (Shukla and Radin, 1990) and it was of interest to see if the enzymes in the other membranes were similar in their sensitivity to gangliosides. The inhibitory effect was distinctly less in these particles: $17 \%$ and $29 \%$ at $60 \mu M$ GDla for the $755 g$ and $12,000 \mathrm{~g}$ particles, respectively, compared with $77 \%$ for microsomes. Although the difference could be attributed to qualitatively different glucosyltransferases, it seems more likely that it is due to differences in the amounts of ganglioside-binding protein or other material in the different preparations. Several such agents have been characterized (Thompson et al., 1986; Tiemeyer et al., 1989; Sonnino et al., 1989).

This possibility was examined by incubating microsomes with boiled microsomes, bovine serum albumin, or fetuin from fetal calf serum (6.8\% sialic acid). In the absence of ganglioside, the proteins had no effect (Fig. 2). Without added proteins, GDla produced marked inhibition. All three preparations, especially the boiled microsomes, reduced the effectiveness of the ganglioside. This finding supports the above interpretation. Serum albumin, of course, is known for its ability to bind a wide variety of lipids, including gangliosides (Venerando et al., 1982). The ability of albumin to reverse the inhibitory effect of ganglioside indicates that the binding constant for the complexing of GDla and enzyme is not much lower than that for albumin and GDla.

The binding material appears to be present also in undenatured microsomes, as shown by evaluating the effect of changing the weight of intact microsomes in the incubation tubes (Fig. 3). In the absence of GD1a, 


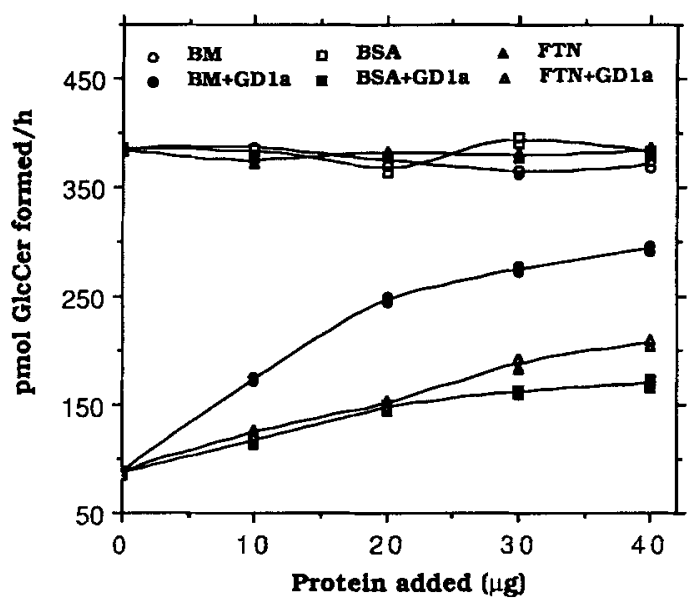

FIG. 2. Effect of proteins on inhibition of microsomal GicCer synthase by $50 \mu \mathrm{M}$ GD1a. Conditions as in Fig. 1. Each symbol shows the value from one assay tube; many of the duplicate points are too close to distinguish as separate symbols. BM, boiled microsomes; FTN, fetuin.

the observed enzyme activity was proportional to the weight of microsomes. When GDla was included, its inhibitory effect was strongest at the low levels of microsomes, evidently because of the low amount of ganglioside-binding material in these tubes. Above $50 \mu \mathrm{g}$ of microsomal protein, the ganglioside had only a small effect.

The degree of inhibition by GDla was independent of time over a 2-h period and the effect appeared even at the first time point studied, 15 min. Thus the ganglioside does not act by destabilizing the enzyme.

In the absence of substrates, the transferase is unstable at $37^{\circ} \mathrm{C}$. In the absence of ganglioside, a 10-min preincubation with $\mathrm{C}_{8}$ ceramide and nonradioactive UDP-Glc (bottom line of Table 1), followed by addition

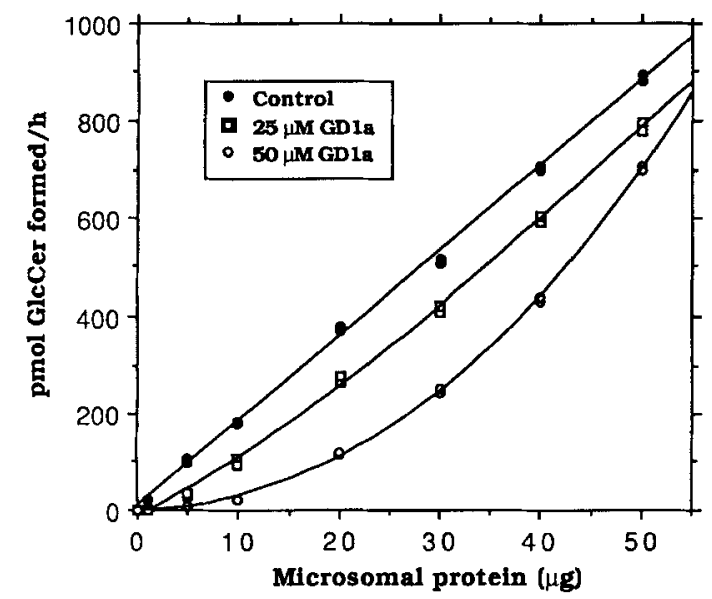

FIG. 3. Relationship between microsome weight and the inhibitory effect of GD1a on GlcCer synthase. Each symbol shows the value from one assay tube; many of the duplicate points are too close to distinguish as separate symbols.
TABLE 1. Effect of preincubating mouse brain microsomes for 10 min on the inhibitory effect of $50 \mu \mathrm{M}$ ganglioside GDla added prior to preincubating

\begin{tabular}{lcr}
\hline \multicolumn{1}{c}{ Preincubation conditions } & Without GD1a & With GD1a \\
\hline UDP-Glc & $328 \pm 5$ & $78 \pm 2$ \\
Ceramide (octanoyl sphingosine) & $363 \pm 5$ & $98 \pm 2$ \\
No substrates & $304 \pm 5$ & $55 \pm 2$ \\
Both substrates & $382 \pm 5$ & $111 \pm 2$ \\
\hline
\end{tabular}

Data are picomoles of GlcCer formed \pm SD after triplicate 60 -min incubations with $20 \mu \mathrm{g}$ of microsomal protein.

of undiluted $\left[{ }^{3} \mathrm{H}\right]$ UDP-Glc and incubation for $1 \mathrm{~h}$, yielded almost the same amount of GlcCer as nonpreincubated tubes. If both substrates were omitted during the preincubation, there was a $20 \%$ loss in activity. Omitting either one of the substrates caused a smaller loss, indicating that both compounds stabilized the enzyme.

When ganglioside was included in preincubation medium with both substrates, there was $71 \%$ inhibition. When both substrates were omitted during the preincubation, the ganglioside was even more effective$82 \%$ inhibition. Thus the ganglioside may compete with both substrates for sites on the enzyme. Not shown in the table is the inhibition seen when the partially inactivated enzyme was exposed to ganglioside after the preincubation period; here the inhibition was only $55 \%$. It is possible that the partially denatured enzyme has a lower affinity for the inhibitor.

When the preincubations were carried out at $0^{\circ} \mathrm{C}$, there was almost no loss of enzyme activity or any effect on the magnitude of the inhibitory effect of ganglioside. When $50 \mu M$ GD la was preincubated at $37^{\circ} \mathrm{C}$ for $10 \mathrm{~min}$ with microsomes and nonradioactive cocktail in a small volume, then diluted up to four times with radioactive cocktail and incubated for $60 \mathrm{~min}$, the amount of inhibition was substantially the same in all tubes (data not shown). This suggests that the enzyme bound fairly strongly to the ganglioside; the complex did not dissociate due to dilution.

To test this hypothesis further, we preincubated brain and liver microsomes with $50 \mu M$ GD1a for $10 \mathrm{~min}$ at $37^{\circ} \mathrm{C}$, then diluted the suspension 10 times with water and centrifuged it for $60 \mathrm{~min}$ at $100,000 \mathrm{~g}$ to recover the particles. When the particles ( $40 \mu \mathrm{g}$ of protein) were incubated in the standard assay system in triplicate for $30 \mathrm{~min}$ with the ceramide liposomes, the ganglioside-treated particles were found to exhibit lower activities. With brain, the control microsomes synthesized $350 \pm 1 \mathrm{nmol}$ of GlcCer; the pretreated particles synthesized $195 \pm 0.8 \mathrm{nmol}$ of GlcCer. From this it would appear that the particles had absorbed enough ganglioside to inhibit the synthase by $56 \%$, despite the washing step. With liver, the corresponding figures were $107 \pm 0.5$ and $63 \pm 0.3$, for an inhibition of $41 \%$.

Another set of tubes was incubated without ceramide liposomes, to see if ganglioside inhibited the synthesis 
of GlcCer when the endogenous ceramides acted as glucose acceptor. The synthesis of GlcCer from the endogenous ceramides was zero for brain (indicating unavailability or absence of microsomal ceramides). With liver membranes the incubation yielded $30 \pm 0.2 \mathrm{nmol}$ of GlcCer for the controls and $22 \pm 0.2 \mathrm{nmol}$ for the GDla-treated membranes, for an inhibition of $27 \%$. Thus the inhibitory action of gangliosides on GlcCer synthase is not an artefact due to using the more reactive octanoyl sphingosine or a liposomal substrate.

Because gangliosides form complexes with divalent metallic cations, of varying degrees of association, it was of interest to determine whether cations influence the inhibitory effect (Table 2). With different $\mathbf{M n}^{2+}$ concentrations, the basal system showed maximal enzyme activity at $10 \mathrm{~m} M$ (the concentration used in all other experiments). Inhibition by GD1a was seen at all concentrations of $\mathrm{Mn}^{2+}$, so it appears that a cation is not involved in formation of the enzyme-ganglioside complex. In the case of $\mathrm{Mg}^{2+}$ and $\mathrm{Ca}^{2+}$, the basal system was most highly activated at $15 \mathrm{mM}$. The effectiveness of $\mathrm{Ca}^{2+}$ is a new finding for brain microsomal glucosyltransferase; however, we did find similar stimulation by $\mathrm{Ca}^{2+}$ in whole kidney homogenates (Shukla and Radin, 1990). The inhibitory effect of ganglioside was reduced by high concentrations of all three cations, particularly $\mathrm{Ca}^{2+}$. This effect was probably due to competitive complexing of the ganglioside by cations instead of by enzyme.

When the basal enzyme cocktail was modified by omitting single components (EDTA, DTE, and ATP), the inhibitory effect of GDla was not much different. However, the inhibition was consistently a little smaller in the absence of ATP. Similar inhibition was produced

TABLE 2. Effect of differing cation concentrations on the inhibitory activity of ganglioside GDla

\begin{tabular}{cccccccc}
\hline $\begin{array}{c}\text { [Cation] } \\
(\mathrm{m} M)\end{array}$ & $\mathrm{GD} 1 \mathrm{a}$ & $\mathrm{Mn}^{2+}$ & & $\mathrm{Mg}^{2+}$ & & $\mathrm{Ca}^{2+}$ & \\
\hline 0 & - & 225 & & 223 & & 227 & \\
& + & 116 & $-29 \%$ & 156 & $-30 \%$ & 161 & $-29 \%$ \\
2.5 & - & 242 & & 238 & & 239 & \\
& + & 165 & $-32 \%$ & 169 & $-29 \%$ & 170 & $-29 \%$ \\
5 & - & 302 & & 277 & & 284 & \\
& + & 211 & $-30 \%$ & 202 & $-27 \%$ & 219 & $-23 \%$ \\
& + & & & & & \\
10 & - & 388 & & 331 & & 327 & \\
& + & 283 & $-27 \%$ & 248 & $-25 \%$ & 271 & $-17 \%$ \\
15 & - & 316 & & 342 & & 339 & \\
& + & 240 & $-24 \%$ & 263 & $-23 \%$ & 250 & $-13 \%$ \\
20 & - & 249 & & 321 & & 336 & \\
& + & 207 & $-17 \%$ & 289 & $-10 \%$ & 306 & $-9 \%$ \\
\hline
\end{tabular}

The standard incubation conditions were used, with $20 \mu \mathrm{g}$ of microsomal protein and without the usual $\mathrm{Mn}^{2+}$. A minus sign indicates no ganglioside was present; a plus sign indicates the presence of 25 $\mu M \mathrm{GD}$ la. The activities shown are the means of duplicate assays, in picomoles per hour of GlcCer formed.

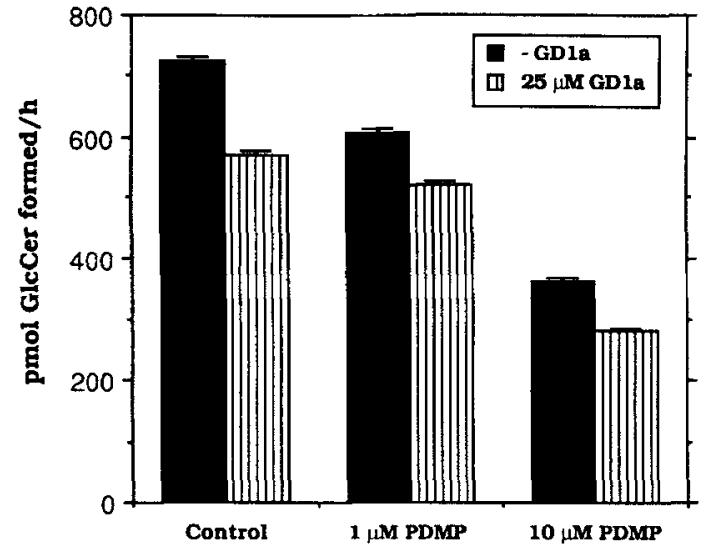

FIG. 4. Effects of two inhibitors, ganglioside GD1a and PDMP, on the synthesis of GlcCer by $37.5 \mu \mathrm{g}$ of microsomal protein, incubated as described in the legend to Fig. 1. The error bars indicate the $S D$ values obtained from three incubation tubes.

by GDla when the octanoyl sphingosine was replaced with other ceramides (octanoyl phytosphingosine and long-chain mixed ceramides).

D-threo-1-Phenyl-2-decanoylamino-3-morpholino1-propanol (PDMP), a cationic ceramide analog, is a stronger inhibitor of ceramide glucosyltransferase, acting as an uncompetitive inhibitor against UDP-Glc and a mixed-type competitor against ceramide (Inokuchi and Radin, 1987). This suggests that the cationic lipid binds to the ceramide-binding catalytic site as well as a more distant site. Because gangliosides contain a ceramide moiety, it seemed possible that both inhibitors bind to a similar region in the catalytic site and another similar region in an effector site. When the two inhibitors were compared separately and together (see bars 3-6, Fig. 4), the extra inhibition produced by adding ganglioside to the PDMP-containing tubes was independent of the PDMP concentration. Thus it would appear that the two inhibitors act, in part, at different sites on the enzyme.

When we examined two common acidic lipids, phosphatidylserine and oleic acid, we found that they were rather weak inhibitors of glucosyltransferase (Fig. 5). Phosphatidylserine partially blocked the inhibitory action of GDla (bar 4 versus bar 2) and, in combination with oleic acid (bar 8 versus bar 7), it prevented the inhibition completely. This may indicate that the acidic lipids compete for the same sites on the enzyme molecule. However, another possibility is that the acidic lipids formed a complex with the ganglioside and $\mathrm{Mn}^{2+}$, preventing GDla uptake by the membrane.

A kinetic analysis of the effect of GDla with regard to UDP-Glc (Fig. 6) showed that the ganglioside acts as a mixed type inhibitor, possibly at the active site and at some other site. The $K_{\mathrm{m}}$ and $V_{\max }$ values for the uninhibited enzyme were $35 \mu M$ and $21 \mu \mathrm{mol} / \mathrm{h} / \mathrm{mg}$ of protein, respectively. For the inhibited enzyme $(25$ $\mu M$ GD 1a) these values were 44 and 16 , respectively. 


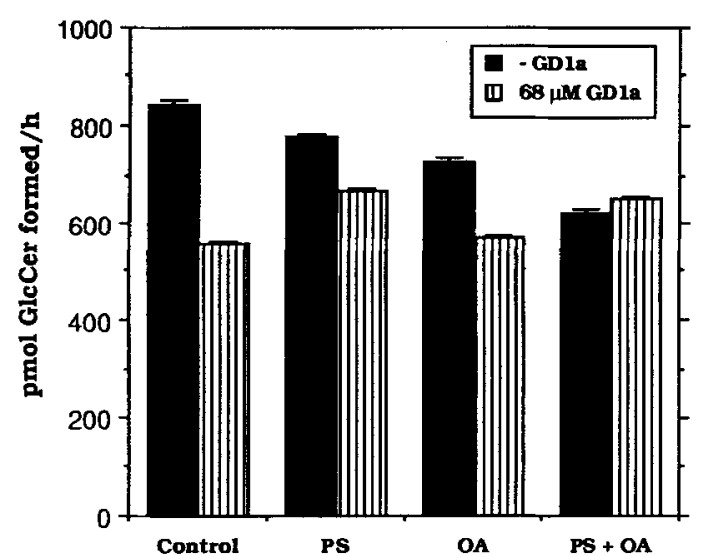

FIG. 5. Interaction between ganglioside, phosphatidylserine (PS, $0.25 \mathrm{mM}$ ), and oleic acid (OA, $0.75 \mathrm{mM}$ ), with respect to the activity of microsomal (44 $\mu \mathrm{g}$ of protein) glucosyltransferase. The error bars indicate the SD values obtained from three incubation tubes.

With regard to octanoyl sphingosine, the $K_{\mathrm{m}}$ and $V_{\max }$ values for the uninhibited enzyme were $30 \mu M$ and $18.5 \mu \mathrm{mol} / \mathrm{h} / \mathrm{mg}$ of protein, respectively (Fig. 7). The ganglioside did not change the $K_{\mathrm{m}}$ for ceramide but did lower the $V_{\max }$ by $31 \%$, so apparently it acts against the ceramide as a noncompetitive inhibitor by binding to the enzyme at a noncatalytic site that slows the enzyme. From these two evaluations, it seems likely that the ceramide moiety of gangliosides binds to the same effector site as the lipoidal substrate and the sialooligosaccharide moiety binds to a region close to the catalytic site, in competition with the nucleotide sugar.

When octanoyl phytosphingosine was used as the lipoidal substrate, it was found to be a markedly better substrate than the nonhydroxy compound with brain, liver, and kidney microsomes. With brain, the $K_{\mathrm{m}}$ and $V_{\max }$ values for the uninhibited enzyme were $15 \mu M$

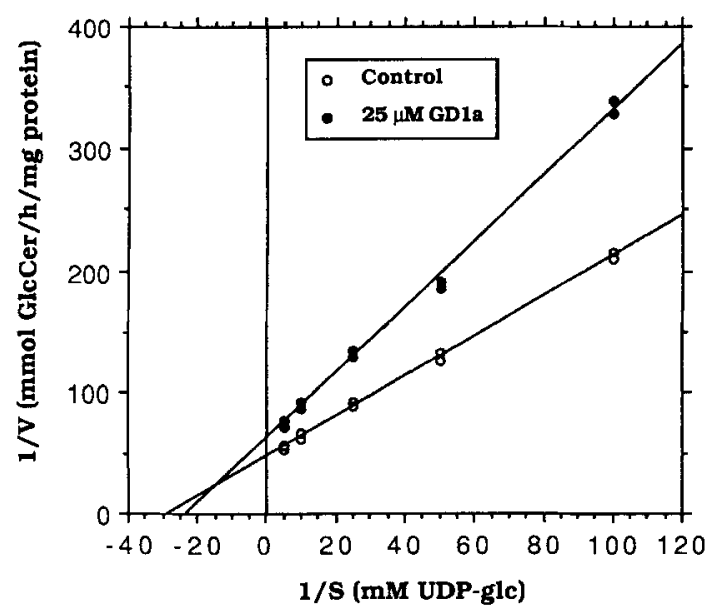

FIG. 6. Lineweaver-Burk plot relating GlcCer synthesis by microsomes ( $20 \mu \mathrm{g}$ of protein) to UDP-Glc concentration. Each symbol shows the value from one assay tube; many of the duplicate points are too close to distinguish as separate symbols.

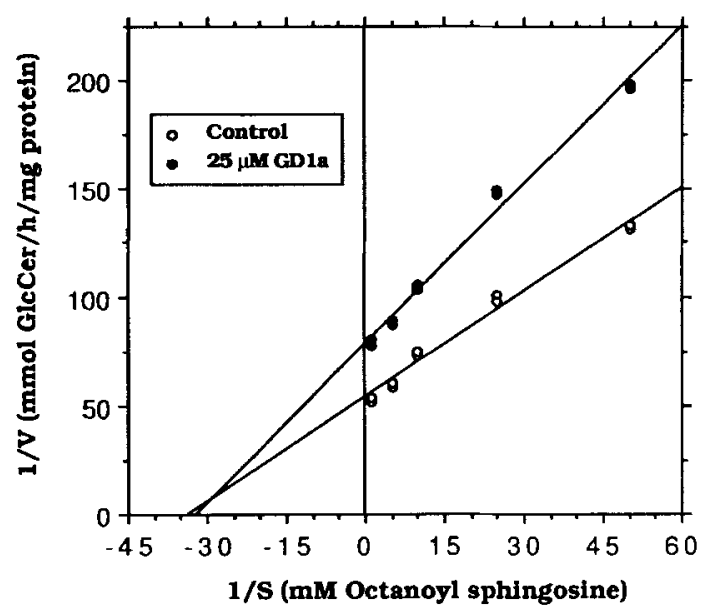

FIG. 7. Lineweaver-Burk plot relating GlcCer synthesis to concentration of $N$-octanoyl sphingosine. Each symbol shows the value from one assay tube; many of the duplicate points are too close to distinguish as separate symbols.

and $32 \mu \mathrm{mol} / \mathrm{h} / \mathrm{mg}$ of protein. Here too the ganglioside resulted in noncompetitive inhibition. It is interesting that phytosphingosine GSLs occur primarily in kidney and intestine of mammals, not in brain. Perhaps the lack of this sphingol in brain GSLs is due to lack of the base rather than to lack of enzymes for utilizing it.

The mechanism of inhibitory action by gangliosides apparently involves binding of the acidic lipid to the enzyme, because we have shown that GDla acts as a mixed type inhibitor toward the nonlipid substrate, UDP-Glc. The possibility that they act by affecting the liposomal structure of the substrate is low because, as noted above, we found that GD1a is inhibitory even when endogenous ceramides (containing long-chain fatty acids) act as glucose acceptor. It is unlikely that gangliosides, which are carboxylic acids, can act as detergents and affect liposomes in our incubation media, which contain a high level of divalent cations. Oleic acid, which is a good detergent in the $\mathrm{Na}^{+}$form, is also inactive as a detergent in our media and was a weak inhibitor in our system (Fig. 5). Even a commercial high-efficiency detergent, such as Triton X-100, has little detergency power at concentrations below 500 $\mu \mathrm{g} / \mathrm{ml}$; in our system, gangliosides at $\sim 100 \mu \mathrm{g} / \mathrm{ml}$ were effective inhibitors. It may be noted that cerebroside sulfate, which might have some detergent properties even in a $\mathrm{Mn}^{2+}$-containing medium, is a component of our ceramide liposomes and is a modest stimulator in our assay system. Omission of the sulfatide from the substrate liposomes did not affect the degree of inhibition by ganglioside.

The competition for ganglioside molecules between GlcCer synthase and other ganglioside-binding substances may explain several phenomena. For example, the $B$ subunit of cholera toxin binds strongly to ganglioside GM1 in rat thymocytes and its exogenous addition to the cells could be expected to relieve the normal inhibitory effect of GMI on GlcCer synthesis. The 
resultant increase in GlcCer might then induce the cell proliferation that was observed experimentally (Spiegel et al., 1985). A partial test of this idea was carried out by testing the ability of cholera toxin B subunit to block the inhibitory effect of ganglioside GM1 (Fig. 8). The toxin preparation itself had some inhibitory effect on the glucosyltransferase, possibly due to the $\mathrm{NaCl}$ in the Sigma preparation (no. C-7771, from Vibrio cholerae). It was apparent that it blocked the inhibition by GM1 in a dose-related manner. Evidently the toxin has a higher affinity than GlcCer synthase for GM1. Variations in the concentrations of the various natural ganglioside-binding tissue components may act to control GlcCer synthesis.

Because gangliosides have been found to produce therapeutic effects in vivo, but by an unknown mechanism, we tested their effect on GlcCer synthase after injection. Groups of six mice each (35-37 g) were injected intraperitoneally daily for 5 days with $50 \mathrm{mg} /$ $\mathrm{kg}$ of mixed brain gangliosides in saline, and killed 3 $\mathrm{h}$ after the last injection. [This dosage level had been used by Sparrow and Grafstein (1982) and Gorio et al. (1980).] Homogenates of brain, liver, and kidney were assayed for GlcCer synthase (Table 3). In the case of kidney, NAD was included in the assay tubes (Shukla and Radin, 1990). Significantly lower levels of enzyme activity were observed, especially with liver.

\section{DISCUSSION}

Our finding that GlcCer synthesis can be slowed by gangliosides raises the question of therapeutic and physiological relevance of the finding: do cellular gangliosides, exogenous or endogenous, actually modulate the level of GlcCer and (indirectly) the levels of the higher GSLs? One criterion is that of concentration

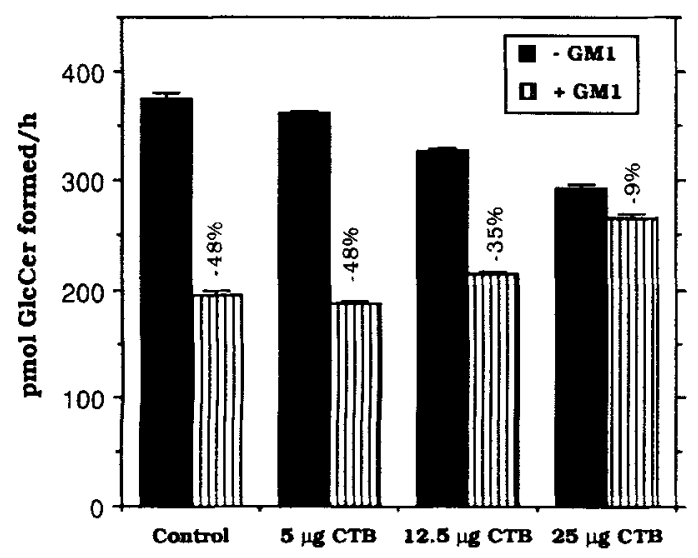

FIG. 8. Inhibition of GlcCer by ganglioside GM1 and reversal of the effect by cholera toxin B (CTB) subunit. The toxin solution contained $500 \mu \mathrm{g}$ of protein (35 toxoid units $/ \mu \mathrm{g}$ ) in $50 \mathrm{mM}$ Tris, $\mathrm{pH} 7.5 ; 200 \mathrm{mM} \mathrm{NaCl} ; 3 \mathrm{mM} \mathrm{NaN}{ }_{3}$; and $1 \mathrm{mM} \mathrm{Na}$ EDTA. Each tube, except the controls, contained $50 \mu M \mathrm{GM} 1$ and various amounts of toxin solution. Triplicate tubes were incubated for 60 min and the means and SD values are shown.
TABLE 3. Effect of injected gangliosides on the activity of ceramide glucosyltransferase

\begin{tabular}{lccc}
\hline & & GD1a & \\
Organ analyzed & Control mice & mice & Percent inhibition \\
\hline Brain & $554 \pm 22$ & $495 \pm 25$ & 11 \\
Liver & $370 \pm 31$ & $270 \pm 14$ & 27 \\
Kidney & $680 \pm 26$ & $619 \pm 23$ & 9 \\
\hline
\end{tabular}

Each value is the activity of the enzyme, in $\mathrm{pmol} / 30 \mathrm{~min} / 3 \mathrm{mg}$ tissue $\pm \mathrm{SD}$. Control mice received saline and experimental mice received $50 \mathrm{mg} / \mathrm{kg}$ of brain gangliosides in saline intraperitoneally daily for 5 days. All three decreases are significant. $p<0.0001$.

sensitivity versus ganglioside concentrations found in tissues. In human brain gray matter, the concentration of total gangliosides was found to be $\sim 1,000 \mathrm{nmol} / \mathrm{g}$ (Kishimoto and Radin, 1965), which is roughly 20 times the concentration needed to produce strong inhibition in our microsomal assay. This comparison is not simple because most of the ganglioside in tissues is surely already bound to specific proteins, including, perhaps, GlcCer synthase. Nevertheless, the contrast in concentrations suggests that a small release or exogenous addition of gangliosides could act physiologically as a negative modulator of GSL synthesis. The above proposed normal role for ganglioside is consistent with the observation that the measured activity of GlcCer synthase in brain drops off sharply as the ganglioside concentration approaches a maximum and cell proliferation slows (Brenkert and Radin, 1972).

Such an effect could also occur in neurologically damaged patients and in animals that are injected with gangliosides [see reviews by Ledeen (1987) and Mahadik and Karpiak (1988)]. In this type of therapy, large amounts of ganglioside are injected for many days and it might thus be possible to attribute the beneficial actions of the lipids to a slowing in GlcCer synthesis. The resulting decrease in GlcCer level might slow any undesirable cell proliferation that may occur after brain damage. In support of this hypothesis are articles showing that exogenous gangliosides inhibit cell growth (Bremer et al., 1984; Sobue et al., 1988) as well as the articles that link GlcCer levels to cell growth rates (see introductory section). Several enzymes have been found to be modulated as the result of injecting gangliosides into animals (cited by Mahadik and Karpiak, 1988).

Further supporting our hypothesis that gangliosides can actually inhibit GlcCer synthase in vivo is our finding that gangliosides injected at a therapeutic level produced a distinct lowering in the glucosyltransferase activity in the three organs studied (Table 3 ). We interpret this to mean that the tissues retained enough of the injected lipid to reduce the GlcCer synthase even when diluted for the assay procedure. It is possible that some of the observed decrease in activity was due to a more complex effect, such as a reduction in the level of mRNA responsible for synthesizing the enzyme. 
However, inhibitors usually produce an increased level of enzyme synthesis through a feedback relationship.

There is evidence that malignant tumors shed or excrete relatively large amounts of ganglioside (Schulz et al., 1984; Ladisch et al., 1987; Bergelson et al., 1989). It has been proposed that these lipids are responsible for the disappointing adequacy of the patient's immune system response to tumor antigens. With certain tumors there is enough shed GSL to make the tumor's presence detectable in the blood, so that a diagnostic or prognostic test is feasible. Such secretion may saturate the body's-and particularly the immunogenic cells'-normally binding ganglioside sites and thus lead to inhibition of the cells' GlcCer synthase. Because the evidence cited above ties GlcCer levels to proliferation rates, this could explain why the immunorejection system in patients fails to reject tumor antigens and why cancer patients lose weight. $T$ cells that were depleted of GlcCer and other GSLs by treatment with the synthase inhibitor PDMP failed to proliferate when exposed to mitogens (Felding-Habermann et al., 1990). Mice treated with PDMP lost weight quickly (Inokuchi et al., 1987).

Additional support for this hypothesis comes from reports that gangliosides suppressed murine and human lymphocyte proliferation and interleukin 1 production in vitro (Whisler and Yates, 1980; Jeng et al., 1988). The plasma gangliosides from mice bearing the Ehrlich ascites tumor were found to enhance the growth of the tumor cells when the cells were inoculated into new animals together with the gangliosides (Saha and Ghosh, 1990). This effect could be due to blockage of the host's immunogenic system. The level of ganglioside-linked sialic acid in several cases of cancer patients was found to be $\sim 33 \mu M$, high enough perhaps to inhibit GlcCer synthase in the patient's body (Kloppel et al., 1977). In addition, it is possible that tumor cells have an unusual ability to shed themselves of gangliosides (due to lack of binding proteins) and can therefore relieve their own GlcCer synthase from the normal amount of inhibition; this could enhance tumor cell proliferation.

Our postulated role for gangliosides in controlling GlcCer levels is given strong support by the previous demonstration that these GSLs also stimulate GlcCer glucosidase (Mueller and Rosenberg, 1979; Sarmientos et al., 1986). This effect would augment the inhibitory action on the synthase, helping to lower cellular GlcCer levels even further. Supporting this conclusion are the findings that gangliosides of different structures produced parallel effects on the two enzymes (Fig. 1). These dual GlcCer lowering effects of gangliosides could explain the observation that exogenous gangliosides stimulate the breakdown of phosphoinositides by a mechanism that does not involve the stimulation of neurite outgrowth (Vaswani et al., 1990). We have recently shown that depletion of kidney cell GlcCer by PDMP enhances the cells' ability to respond to stimulation by bradykinin, which normally activates the hydrolysis of phosphatidylinositol diphosphate (Shayman et al., 1990). Thus, a lack of GlcCer, produced by PDMP or by ganglioside, enhances the hydrolysis of inositol lipid.

Our postulated modulating roles of gangliosides described above should not be construed as implying that the known specific binding and enzyme-activating properties of gangliosides have no function or that the many observations made with GSLs can be explained via only one property. Ganglioside effects that take some time to become evident are more likely to be due to the GlcCer-lowering mechanism.

A study of GM3:UDP- $N$-acetylgalactosamine aminosugar transferase in microsomes from chicken retina (Nores and Caputto, 1984) revealed that this enzyme resembles glucosyltransferase with regard to its interactions with gangliosides. As in our system, gangliosides were found to inhibit strongly (but at higher ganglioside concentrations), to bind to the microsomes, and to inhibit more effectively at lower microsome concentrations than at higher concentrations. An earlier study of this enzyme, using Tay-Sachs brain, also reported the inhibitory effect of gangliosides (Yu et al., 1983). The assay system included Triton X-100, so it is clear that the presence of a detergent did not block the effect of the sialolipids. An important conclusion from this study, very relevant to our conclusions, is that the known accumulation of GM3 and GD3 in Tay-Sachs brain is due to the inhibitory action of the accumulated galactosaminyl gangliosides in these patients.

Another enzyme in the GSL series, GM3 synthase of rat liver Golgi apparatus, was also found to be inhibited by various gangliosides, but at very high concentrations (Richardson et al., 1977).

Acknowledgment: This work was supported in part by NIH Grant NS 03192. N.S.R. is an N.I.H. Senator Jacob Javits Neuroscience awardee.

\section{REFERENCES}

Bergelson, L. D., Dyatlovitskaya E. V., Klyuchareva T. E., Kryukova E. V., Lemenovskaya A. F., Matveeva V. A., and Sinitsyna E. V. (1989) The role of glycosphingolipids in natural immunity. Gangliosides modulate the cytotoxicity of natural killer cells. Eur. J. Immunol. 19, 1979-1983.

Braun P. E., Morell P., and Radin N. S. (1970) Synthesis of $C_{18-}$ and $\mathrm{C}_{20}$-dihydrosphingosines, ketodihydrosphingosines, and ceramides by microsomal preparations from mouse brain. J. Biol. Chem. 245, 335-341.

Bremer E. G., Hakomori S., Bowen-Pope D. F., Raines E., and Ross R. (1984) Ganglioside-mediated modulation of cell growth, growth factor binding, and receptor phosphorylation. J. Biol. Chem. 259, 6818-6825.

Brenkert A. and Radin N. S. (1972) Synthesis of galactosyl ceramide and glucosyl ceramide by rat brain: assay procedures and changes with age. Brain Res. 36, 183-193.

Datta S. C. and Radin N. S. (1988) Stimulation of liver growth and DNA synthesis by glucosylceramide. Lipids 23, 508-510.

Felding-Habermann B., Igarashi Y., Fenderson B. A., Park L. S., Radin N. S., Inokuchi J., Strassmann G., Handa K., and Hakomori S. (1990) A ceramide analog inhibits T cell proliferative response through inhibition of glycosphingolipid synthesis and 
enhancement of $N, N$-dimethylsphingosine synthesis. Biochemistry 29, 6314-6322.

Gorio A., Carmignoto G., Facci L., and Finesso M. (1980) Motor nerve sprouting induced by ganglioside treatment. Possible implications for gangliosides on neuronal growth. Brain Res. 197, 236-241.

Hara A. and Radin N. S. (1979) Enzymic effects of $\beta$-glucosidase destruction in mice. Biochim. Biophys. Acta 582, 423-433.

Inokuchi J. and Radin N. S. (1987) Preparation of the active isomer of 1-phenyl-2-decanoylamino-3-morpholino-1-propanol, inhibitor of glucocerebroside synthetase. J. Lipid Res. 28, 565571.

Inokuchi J., Mason I., and Radin N. S. (1987) Antitumor activity in mice of an inhibitor of glycosphingolipid biosynthesis. Cancer Lett. 38, 23-30.

Inokuchi J., Momosaki K., Shimeno H., Nagamatsu A., and Radin N. S. (1989) Effects of D-threa-PDMP, an inhibitor of glucosylceramide synthetase, on expression of cell surface glycolipid antigen and binding to adhesive proteins by B 16 melanoma cells. J. Cell. Physiol. 141, 573-583.

Inokuchi J., Jimbo M., Momosaki K., Shimeno H., Nagamatsu A., and Radin N. S. (1990) Inhibition of metastasis of murine Lewis lung carcinoma by an inhibitor of glucosylceramide synthase and its possible mechanism of action. Cancer Res. 50, 67316737.

Jeng K. G., Chen T., and Lan J. (1988) Gangliosides suppression of murine lymphoproliferation and interleukin 1 production. $I \mathrm{~m}$ munol. Lett. 19, 335-340.

Kishimoto Y. and Radin N. S. (1965) Determination of brain gangliosides by determination of ganglioside stearic acid. J. Lipid Res. 7, 141-145.

Kloppel T. M., Keenan T. W., Freeman M. J., and Morré D. J. (1977) Glycolipid-bound sialic acid in serum: increased levels in mice and humans bearing mammary carcinomas. Proc. Natl. Acad. Sci. USA 74, 3011-3013.

Ladisch S., Wu Z., Feig S., Ulsh L., Schwartz E., Floutsis G., Wiley F., Lenarsky C., and Seeger R. (1987) Shedding of GD2 ganglioside by human neuroblastoma. Int. J. Cancer 39, 73-76.

Ledeen R. W. (1987) Biology of gangliosides: neuritogenic and neuronotrophic properties. J. Neurosci. Res. 12, 147-159.

Mahadik S. P. and Karpiak S. K. (1988) Gangliosides in treatment of neural injury and disease. Drug Dev. Res. 15, 337-360.

Mueller O. T. and Rosenberg A. (1979) Activation of membranebound glucosylceramide: $\beta$-glucosidase in fibroblasts cultured from normal and glucosylceramidotic human skin. J. Biol. Chem. 254, 3521-3525.

Nores G. A. and Caputto R. (1984) Inhibition of the UDP- $N$-acetylgalactosamine:GM3 $N$-acetylgalactosaminyl transferase by gangliosides. J. Neurochem. 42, 1205-1211.

Richardson C. L., Keenan T. W., and Morré D. J. (1977) Characterization of CMP- $N$-acetylneuraminic acid:lactosylceramide sialyltransferase in Golgi apparatus from rat liver. Biochim. Biophys. Acta 488, 88-96.

Saha S. and Ghosh A. (1990) Effect of plasma gangliosides on the growth of Ehrlich ascites tumor. Int. J. Cancer 46, 691-694.

Sarmientos F., Schwarzmann G., and Sandhoff K. (1986) Specificity of human glucosylceramide $\beta$-glucosidase towards synthetic glucosylsphingolipids inserted into liposomes. Eur. J. Biochem. 160, 527-535.

Schulz G., Cheresh D. A., Varki N. M., Yu A., Staffileno L. K., and Reisfeld R. A. (1984) Detection of ganglioside GD2 in tumor tissues and sera of neuroblastoma patients. Cancer Res. 44, 59145920.

Shayman J. A., Mahdiyoun S., Deshmukh G., Barcelon F., Inokuchi J., and Radin N. S. (1990) Glucosphingolipid dependence of hormone-stimulated inositol trisphosphate formation. J. Biol. Chem. 265, 12135-12138.

Shukla G. S. and Radin N. S. (1990) Glucosylceramide synthase of mouse kidney: further characterization with improved assay method. Arch. Biochem. Biophys. 283, 372-378.

Smith P. K., Krohn R. I., Hermanson G. T., Mallia A. K., Gartner F. H., Provenzano M. D., Fujimoto E. K., Goeke N. M., Olson B. J., and Klenk D. C. (1985) Measurement of protein using bicinchoninic acid. Anal. Biochem. 150, 76-85.

Sobue G., Taki T., Yasuda T., and Mitsuma T. (1988) Gangliosides modulate Schwann cell proliferation and morphology. Brain Res. 474, 287-295.

Sonnino S., Chigorno V., Acquotti D., Pitto M., Kirschner G., and Tettamanti G. (1989) A photoreactive derivative of radiolabeled GM 1 ganglioside: preparation and use to establish the involvement of specific proteins in GMl uptake by human fibroblasts in culture. Biochemistry 28, 77-84.

Sparrow J. R. and Grafstein B. (1982) Sciatic nerve regeneration in ganglioside-treated rats. Exp. Neurol. 77, 230-235.

Spiegel S., Fishman P. H., and Weber R. J. (1985) Direct evidence that endogenous GM1 ganglioside can mediate thymocyte proliferation. Science 230, 1285-1287.

Thompson L. K., Horowitz P. M., Bentley K. L., Thomas D. D., Alderete J. F., and Klebe R. J. (1986) Localization of the ganglioside-binding site of fibronectin. J. Biol. Chem. 261, 52095214.

Tiemeyer M., Yoshinobu Y., and Schnaar R. L. (1989) Gangliosidespecific binding protein on rat brain membranes. J. Biol. Chem. 264, 1671-1681.

Vaswani K. K., Wu G., and Ledeen R. W. (1990) Exogenous gangliosides stimulate breakdown of Neuro-2A phosphoinositides in a manner unrelated to neurite outgrowth. J. Neurochem. 55, 492-499.

Venerando B., Roberti S., Sonnino S., Fiorilli A., and Tettamanti G. (1982) Interactions of ganglioside GM1 with human and fetal calf sera. Formation of ganglioside-serum albumin complexes. Biochim. Biophys. Acta 692, 18-26.

Vunnam R. R. and Radin N. S. (1979) Short chain ceramides as substrates for glucocerebroside synthetase: differences between liver and brain enzymes. Biochim. Biophys. Acta 573, 73-82.

Whisler R. L. and Yates A. J. (1980) Regulation of lymphocyte responses by human gangliosides. J. Immunol. 125, 2106-2111.

Yu R. K., Itoh T., Yohe H. C., and Macala L. J. (1983) Characterization of some minor gangliosides in Tay-Sachs brains. Brain Res. 275, 47-52.

Zhang H., Buckley N. E., Gibson K., and Spiegel S. (1990) Sphingosine stimulates cellular proliferation via a protein kinase $\mathrm{C}$ independent pathway. J. Biol. Chem. 265, 76-81. 